\title{
ESSAY
}

\section{FORCES AND MECHANISMS IN THE CONSTITUTION-MAKING PROCESS}

\author{
JON ELSTER †
}

\section{INTRODUCTION}

The topic of this Essay is how new constitutions are made, the mechanics of constitution-making. Surprisingly, there is no body of literature that deals with the constitution-making process in a positive, explanatory perspective. There are, to be sure, a number of studies, on which I shall draw heavily, of particular constitution-making episodes. Furthermore, there is a large coinparative and theoretical literature on the ordinary legislative process, as well as a substantial body of writings on comparative constitutional law. Much has also been written on the consequences of constitutional design-presidential versus parliamentary systems, umicanteralism versus bicameralism, and so on. But there is not, to my knowledge, a single book or even article that considers the process of constitution-making, in its full generality, as a distinctive object of positive analysis. ${ }^{1}$ Although the present Essay is by ne-

$\dagger$ Robert K. Merton Professor of Social Science, Columbia University. This Essay was presented as the 1995 Brainerd Currie Lecture at the Duke University School of Law on February 13, 1995. Over the last five years I have discussed constitution-making in Eastern Europe and elsewhere with a number of colleagues. I am especially grateful to Stephen Holmes, Aanund Hylland, Claus Offe, Wiktor Osiatynski, Ulrich Preuss, Adam Przeworski, and Cass Sunstein. I would also like to acknowledge the support of the IRIS project and of the Center for the Study of Constitutionalism in Eastern Europe at the University of Chicago Law School.

1. Among writers who have considered constitution-making in comparative perspcctive, MARKKU SUKSI, MAKING a CONSTITUTION: THE OUTLINE OF AN ARGUMENT (1995) is mainly legal and normative. A more explanatory approach is found in chapter 8 of ANDREA BONIME-BLANC, SPAIN'S TRANSITION TO DEMOCRACY: THE POLITICS OF CONSTIUUTION-MAKING 135-61 (1987), but her discussion is less than fully general. Being limited to transitions from authoritarianism to democracy, it does not, for instance, cover such constitution-naking episodes as the Federal Convention in Philadelphia. The articles in CONSTITUTION MAKERS ON CONSTITUTION MAKING (Robert A. Goldwin \& Art Kaufman eds., 1988) describe individual constitution-making episodes, with no comparative or theoretical perspectives, except for the fact that the contributors were asked to address the same set of questions. PATRICK A. FAFARD \& DARREL R. REID, CONSTITUENT ASSEMBLIES: A COMPARATIVE SURVEY (1991), while useful, is nrainly descriptive (and, 
cessity somewhat sketchy, it takes a few steps towards remedying that deficiency.

Another noteworthy gap in the literature is the absence of normative discussions of the constitution-making process. Towards the end of this Essay, I briefly address the issue of the optimal design of the constitution-making process, an issue that is both separate from and indirectly related to the issue of designing the optimal constitution.

Creating a constitution involves making choices under constraints. In most of the cases that concern me, these are collective choices-the work of a constituent assembly rather than of a single legislator like Solon. We must consider, therefore, both the goals of individual constitution-makers and the mechamisins by which these are aggregated into collective choices. These are the key notions in the Essay: constraints, individual motivations, and systems of aggregation. I shall also consider the cognitive assumptions of the constitution-makers-their behefs about what institutional arrangeinents will bring about which results. These beliefs form the bridge between overall goals and preferences for specific constitutional provisions.

Constitutions can be written or unwritten. Some countries that do have a written constitution also operate through unwritten "constitutional conventions." In the United States, for instance, the independence of the central bank (i.e., the Federal Reserve Board) is not explicitly stated in the constitution, as it is in some other countries. Yet, de facto the Board enjoys considerable autonomy because of a constitutional convention by virtue of which any attempt by the executive or the legislature to interfere with its activities would incur costly pohtical sanctions. Other countries, notably Britain, rely exclusively on constitutional conventions. In this Essay, I am concerned exclusively with the making of written constitutions. The emergence of unwritten conventions is subject to causal mechanisms that remam poorly understood and that are in any case very different from the (mainly) collective dehberations that are the topic of the present Essay. ${ }^{3}$ From now on, then, the

to some extent, prescriptive).

2. GeOFFrey MARShali, CONSTTTUTIONAL CONVENTIONS 9 (1984).

3. For some attempts to explain the emergence of conventions, see JAMES S. Coleman, Foundations of SOCIAL THEORY (1990); JON Elster, THE CEMENT OF SOCIETY (1989); RUSSELl HARDIN, COLLECTIVE ACTION (1982); ANDREW SCHOTTER, 
term "constitution" will always refer to a written document.

If we want to distinguish the constitution from other legal texts, three criteria offer themselves. First, many countries have a set of laws collectively referred to as "the constitution." Second, some laws may be deemed "constitutional" because they regulate matters that are in soine sense more fundamental than others. And third, the constitution inay be distinguished from ordinary legislation by more stringent amendinent procedures. These characterizations, however, do not always yield the same results.

New Zealand has a constitution according to the first and second criteria, but not according to the third. In that country, "only ordinary legislative efforts are required to supplement, modify or repeal the Constitution."

Conversely, Israel has a constitution according to the second and third criteria, but not according to the first. After 1948, there was no agreement on the need for a constitution. Whereas soine "stressed the stabilizing effect of a constitution, which is particularly necessary in a dynamic and volatile population,"s others "stressed the dangers of a rigid constitution, and the likely calanities ensuing from a reactionary supreme court with powers of judicial review, particularly in a dynamic society." Although the latter view prevailed, the Knesset since 1950 has adopted a number of basic laws that satisfy the second and third criteria. They regulate basic matters such as the Knesset itself, Israel Lands, the state president, the government, the state economy, the anny, Jerusalem, capital of Israel, and the judiciary. Most of these laws contam a provision that they cannot be modified during a state of emergency, thus also satisfying the third criterion. In addition, the law on the Knesset is entrenched in the sense of requiring an absolute majority for its amendinent.

THE ECONOMIC THEORY OF SOCIAL INSTITUTIONS (1981); ROBERT SUGDEN, THE ECONOMICS OF RIGHTS, CO-OPERATION AND WELFARE (1986); MICHAEL TAYLOR, ANARCHY AND COOPERATION (1976); EDNA ULLMANN-MARGALIT, THE EMERGENCE OF NORMS (1977).

4. Julian N. Eule, Temporal Limits on the Legislative Mandate: Entrenchment and Retroactivity, 1987 AM. B. FOUND. RES. J. 379, 394 n.61. Eule goes on to say, however, that "[e]ven in such a system ... there remain moral and political restraints on the legislative alteration of constitutional doctrine." Id. In other words, satisfaction of the first criterion may to some extent automatically ensure satisfaction of the third.

5. Emanuel Gutmann, Israel: Democracy Without a Constitution, in ConstrTUTrons IN Democratic Politics 290, 292 (Vernon Bogdanov ed., 1988).

6. Id. at 295 . 
Some countries have a body of "organic laws" that, although not part of the document referred to as "the constitution," require a supermajority for their amendment. In France, the requirement is that of an absolute majority; in Hungary, it is two-thirds.

Some aspects of political life that we tend to think of as fundamental are not regulated by the constitution or not by all constitutions; nor are the laws regulating them always subject to more stringent amendment procedures. The most important example is provided by laws governing elections to parliament. Some constitutions specify the electoral system in soine detail; others (Poland, the Czech Republic) only in general outlines; and soine (France, Hungary) not at all. In Hungary, but not in France, electoral laws are "orgamic" in the sense indicated above. The status of the central bank is similarly omitted from most constitutions or mentioned only in general terms. An exception is the Czecl constitution, which explicitly forbids the governinent from instructing the bank. Even more striking is the absence from all constitutions (known to me) of constitutional provisions ensuring the independence of the state-owned inedia.

The inain explanandum in this Essay is the adoption of a document called "the constitution." In practice, this document will also satisfy the second criterion. All constitutions regulate fundamental matters, altliough not only such inatters nor all such inatters. Witl the exception of New Zealand, it will also satisfy the third criterion. Because of the fundamental importance of electoral laws in regulating pohtical life, I shall often treat thein on a par with constitutional provisions proper. This practice seems especially justified in the cases where the inclusion or noninclusion of electoral laws in the constitution was a matter of debate in the constitution-inaking process, as was the case, for instance, in the makmg of the Constitution of the Fiftl French Republic. ${ }^{7}$ I shall also include in the explanandum the quasi-constitutional Round Table Talks that took place in several East European countries in 1989 and 1990. The Polislı talks, in particular, very explicitly took the form of constitutional bargaining.

7. Alain Peyrefitte, C'Était de Gaulle 452 (1994).

8. For a survey of these events, see Jon Elster, Constitution-making in Eastern Europe: Rebuilding the Boat in the Open Sea, 71 PUB. ADMIN. 169 (1993). 


\section{WAVES OF CONSTITUTION-MAKING}

Let me begin by describing my universe. For reasons that I shall discuss later, constitution-making tends to occur im waves. From the late eighteenth century to the present, one can identify at least seven such waves.

Modern constitution-making began in the late eighteenth century. Between 1780 and 1791, constitutions were written for the various American states, the Umited States, Poland, and France.?

The next wave occurred in the wake of the 1848 revolutions in Europe. ${ }^{10}$ Counting all the small German and Italian states, revolutions took place in more than fifty countries. Many of these also adopted new constitutions-often replaced within a short period by constitutions imposed by the victorious counterrevolutionary forces.

A third wave broke out after the First World War. The newly created or recreated states of Poland and Czechoslovakia wrote

9. Of these, I shall consider only the Federal Convention of 1787 and the French Assemblée Constituante of 1789-1791. Concerning the latter, I have benefited especially from JEAN EGRET, LA REVOLUTION DES NOTABLES (1950) and JEAN EGRET, NECKER, MINESTRE DE LOUIS XVI (1975). Transcripts of the debates are found in ARCHIVES PARLEMENTAIRES DE 1787 A 1860 PREMIiere SÉRIE (1789 A 1799) (1875-1888) [hereinafter ARCHIVES PARLEMENTAIRES], to be supplemented by 1 ORATEURS DE LA RÉvolution FrançAISE: LES CONSTITUANTS (François Furet \& Ran Halévi eds., 1989). For the American debates and their background, I have mainly consulted CALVIN $C$. JiLLSON, CONSTTTUTION MAKING: CONFLICT AND CONSENSUS IN THE FEDERAL CONVENTION OF 1787 (1988); CATHY D. MATSON \& PETER S. ONUF, A UNION OF INTERESTS: POLITICAL AND ECONOMIC THOUGHT IN REVOlUTIONARY AMERICA (1990); and GORDON S. WOOD, THE CREATION OF THE AMERICAN REPUBLIC 1776-1787 (1969). The main documentary sources, including notably James Madison's notes from the Convention, are found in the four volumes of THE RECORDS OF THE FEDERAL CONVENTION OF 1787 (Max Farrand ed., 1966).

10. A comparative study of the 1848 movements is PRISCILLA ROBERTSON, REVOLUTTONS OF 1848 (1952). Useful studies of the making of the 1848 French constitution are PAUL BASTID, DOCTRINES ET INSTITUTIONS POLITIQUES DE LA SECONDE RÉPUBLIQUE (1945), and JACQues COHEN, LA PRÉPARATION DE LA CONSTITUTION DE 1848 (1935). The minutes of the Constitutional Committee are published in PIERo CRAvERI, GENESI DI UNA CONSTTTUZIONE: LIBERTA E SOCIALISMO NEL DIBATTTTO CONSTITUZIONALE DEL 1848 IN FRANCIA 107-210, 223-302 (1985). One member of that committee wrote an extraordinarily insightful analysis of its work. See ALEXIS DE TOCQUEVILLE, RECOLLECTIONS: THE FRENCH REVOLUTION OF 1848 (J.P. Mayer \& A.P. Kerr eds. \& George Lawrence trans., 1987) (1893). The German constitution-Inaking of 1848 is the subject of FrANK EyCK, ThE Frankfurt PARLIAMENT 1848-1849 (1968). See also 2 ERNST R. HuBER, DEUTSCHE VerfasSUNGSGESCHICHTE (1960). 
their constitutions. ${ }^{11}$ The defeated German state adopted the Weimar Constitution. ${ }^{12}$

Next, the fourth wave occurred after the Second World War. The defeated nations-Japan, Germany and Italy-adopted new constitutions under the more or less strict tutelage of the Allied Powers. ${ }^{13}$

A fifth wave was counected with the breakup of the French and British colonial enıpires. It began in India and Pakistan in the 1940s, but the process did not really gain momentum until the 1960s. In many cases, the new constitutions were modeled closely on those of the former colonial powers. To name only a few examples, the constitution of the Ivory Coast was modeled on that of the Fifth French Republic, whereas those of Ghana and Nigeria followed the British "Westminster model."

A next wave is linked to the fall of the dictatorships in Southern Europe in the mid-1970s. Between 1974 and 1978, Portugal, Greece, and Spain adopted new democratic constitutions. ${ }^{14}$

Finally, a number of former Communist countries im Eastern and Central Europe adopted new constitutions after the fall of commumisn in 1989. Although I do not have an exact count, there must be a couple of dozen new constitutions in the region. ${ }^{15}$

I know too hittle about the new constitutions in the ex-colonial countries to take account of them in this Essay. But I shall

11. See agnes headlam-Morley, The New Democratic Constitutions of EUROPE 46-48 (1929).

12. Id. at 44; see also 5 ERNST R. HUBER, DEUTSCHE VERFASSUNGSGESCHICHTE 1178 (1978) (chronicling events leading to the adoption of the Weimar Constitution).

13. Good studies of the naking of the West German Constitution of 1949 (the only one of the post-1945 constitutions to be examined here) include J. FORD GOLAY, THE Founding of THE Federal REPUBlic of Germany (1958) and PETER H. MERKL, THE ORIGIN OF THE West GERMAN REPuBlic (1963). Transcripts of the relevant debates are found in PARLAMENTARISCHER RAT: VERHANDLUNGEN DES HAUPTAUSSCHUSSES (1948-49).

14. For a discussion of Spain's constitution-making process, the only one of this wave that I consider below, see BONIME-BLANC, supra note 1; JOSEP M. COLOMER, GAME THEORY aNd THE TRANSITION TO DEMOCRACY: THE Spanish MOdel (1995); Francisco Rubio Llorente, The Writing of the Constitution of Spain, in CONSTTTUTION MAKERS ON CONSTITUTION MAKING, supra note 1, at 239.

15. See generally E. EUR. CONST. REV. (reporting on the constitution-making process in Eastern and Central Europe); RFE/RL Research Institute, Radio Free Europe/Radio Liberty, Inc., REPORT ON EASTERN EUROPE (1989-1991); RFE/RL Research Institute, Radio Free Europe/Radio Liberty, Inc., RFE/RL RESEARCH REPORT (1991-present). I shall refer to the Radio Free Europe publications as "RFE" followed by the date of publication. A more synthetic exposition is offered in Elster, supra note 8. 
draw on constituent episodes from all the other waves and also on some isolated episodes that were not part of any wave. ${ }^{16}$ Most of my examples will be taken from the American and French assemblies of the 1780s and the East European constituent bodies of the 1990s.

My universe is limited, therefore, to Europe and North America. I shall ignore not only the recent Asian and African constitutions, but also the rich history of constitution-making im Latin America. I simply know too little about the history, culture, and languages of these parts of the world to be able to interpret their constitution-making experiences with any kind of confidence.

Before I deal with the constraints, motivations, and aggregation mechanisnis, let me point to a large fact that may help us understand why constitutions occur in waves. The fact is that new constitutions almost always are written in the wake of a crisis or exceptional circunistance of sonie sort. ${ }^{17}$ There are some exceptions. The Swedish Constitution of 1974, for instance, was made imder entirely undramatic circunistances. ${ }^{18}$ The new Canadian Constitution of 1982 may also count as a counterexainple, although the context here was soniewhat niore tense. By and large, however, the link between crisis and constitution-making is quite robust.

I have identified a nunber of circumstances that induce constitution-nuaking. First, there is social and econonic crisis, as in the

16. These include notably the making of the French Constitution of 1958 and of the Canadian Constitution of 1982. For the former, see JEAN-MARIE DENQUIN, 1958: LA GENÈSE DE LA VE RÉPUBLIQUE (1988) and L'ÉCRITURE DE LA CONSTITUTION DE 1958 (Didier Maus et al. eds., 1992). Documentation and transcripts of relevant debates are found in 1-3 DOCUMENTS POUR SERVIR A L'HISTOIRE DE L'ÉLABORATION DE LA CONSTITUTION DU 4 OCTOBRE 1958 (Comite National Chargé de la Publication des Travaux Préparatoires des Institutions de la Ve République ed., 1987-1991). For the latter, see notably PETER H. RUSSELL, CONSTITUTIONAL OdySSEY: CAN CANADIANS BECOME A SOVEREIGN PEOPLE? (2d ed. 1993). Documentary background is provided in CANADA's CONSTITUTION ACT 1982 \& AMENDMENTS: A DOCUMENTARY History (Anne F. Bayefsky ed., 1989).

17. See Russell, supra note 16, at 106 ("No liberal democratic state has accomplished comprehensive constitutional change outside the context of some cataclysmic situation such as revolution, world war, the withdrawal of empire, civil war, or the threat of imminent breakup.").

18. See generally Olof Ruin, Sweden: The New Constitution (1974) and the Tradition of Consensual Politics, in CONSTTIUTIONS IN DEMOCRATIC PolmTCS, supra note 5, at 309 (describing Sweden's process of constitutional reform, which imcluded two appointed parhamentary commissions and spanned almost two decades before a new constitution was adopted in 1974). 
making of the American Constitution of 1787 or the French Constitution of $1791 .{ }^{19}$ Let me emphasize that the making of the first French constitution was not an effect of the French revolution, but rather its cause: The economic crisis caused the constitution-making process, whicl eventually turned into a political revolution. Second, there is revolution, as in the making of the 1830 Charter in France or the French and German 1848 Constitutions. Third, there is regime collapse, as in the making of the new constitutions im Southern Europe in the mid-1970s and in Eastern Europe in the early 1990s. Fourth, there is fear of regime collapse, as in the making of the French Constitution of 1958, which was imposed by de Gaulle imder the shadow of a military rebellion. The making of the 1791 Pohsh Constitution also illustrates this case. Fifth, there is defeat in war, as in Germany after the First and Second World Wars, or in Italy and Japan after the Second. Sixth, there is reconstruction after war, as in France in 1946. Seventh, there is the creation of a new state, as in Poland and Czechoslovakia after the First World War. Eighth and finally, there is liberation from colonial rule, as in the United States after 1776 and in nany third world countries after 1945.

We are now in a position to understand the plienoinenon of constitution-1naking waves. First, we may dismiss some of the waves as spurious or accidental. The teniporal proximity of the American Constitution of 1787 and the French and Pohsh Constitutions of 1791 is just a coincidence. The same is true, I believe, of the almost simultaneous collapses of the South European dictatorships around 1975. The other waves, however, are nonspurious.

19. With regard to France in 1789 , the assertion of a crisis is a truism. The finances of the kingdom were in a shambles because of military overcommitments. The last harvest had been disastrous, and the winter cruel. Moreover, these acute pressures emerged against a background of chromic anomie. The hierarchies were crumbling. All classes harbored intense resentments, either against each other or against the royal administration. Intellectual criticisin was rampant. Although the direct purpose for calling the Estates General was to raise revenue, they were ineluctably transformed into a general attack on privilege. With regard to America in 1787, the assertion of a general crisis is more controversial. However, although the econoiny was prosperous, there was a widespread behef that the country was badly governed. The state legislatures, according to this perception, acted on partisan and myopic motives, and Congress was too weak to restram or coordinate their behavior. Moreover, many believed that this political misbehavior was having dire economic consequences, such as the printing of paper money, the cancellation of debts, and the confiscation of property. For explanatory purposes, the existence of these beliefs is more important than their accuracy. 
In some cases, the constitution-making episodes came in clusters because they were triggered by the same event. Here, the clustering is explained by the principle "similar causes, similar effects." This argument applies to the waves of constitution-inaking in the United States after 1776, in the third world after decolonization, and in numerous European countries after the First or the Second World War.

In other cases, the triggering events occurred in a chain reaction. By this I do not mean that constitution-1naking in one country triggered constitution-1naking in another, but that the event that caused constitution-making in one country triggered similar events, with constitution-making consequences, in another.

The chain reaction cases can be further subdivided into two categories. First, one triggering event can serve as a cognitive model for another. This was the inechanism by which the outbreak of the French Revolution of 1848 triggered many similar events in Germany. By appealing to this mechamisin we can also assert, I think, that the 1992 breakup of the Czechoslovak federation was triggered by the earher breakups of the Yugoslav and Soviet federations. ${ }^{20}$ What happens in such cases is that courses of action that previously were unthinkable or appeared as inere abstract possibilities suddenly become vivid and reahistic options.

Second, what happens in one country may influence what happens elsewhere by the mechamism of upgrading of beliefs. An example is provided by the classical domino theory that governed American foreign policy for many years. The idea was that if the Americans yielded in, say, Vietnam, this would send a signal to other governments in the region-and to the insurgency moveinents-about the willingness of the Americans to intervene. Much the saine idea underlies recent Russian policy in Chechnya. More relevantly for the present purposes, the 1989-1990 Round Table Talks in Eastern Europe illustrate the same pattern. The lack of Soviet intervention in Poland enabled the Hungarians to upgrade

20. Some scholars who discuss the breakup of Czechoslovakia argue that the abolition of the centralizing Communist regimes combined with long-standing ethnic or national hostilities contributed to the splits. For this "similar causes, similar effects" argument, see Eric Stein, Musings at the Grave of a Federation, in INSTITUMONAL DYNAMICS OF EUROPEAN INTEGRATION: 2 ESSAYS IN HONOUR OF HENRY G. SCHERMERS 641, 647 (Deirdre Curtin \& Ton Heukels eds., 1994). I argue against this interpretation in Jon Elster, Transition, Constitution-making and Separation in Czechoslovakia, 36 ARCHIVES EUROPÉENNES DE SOCIOLOGIE 105 (1995). 
their beliefs about the likelihood of Soviet intervention in their country. For the Czechoslovaks, it was the Soviet nonintervention in East Germany that made them understand that there would not be a repetition of 1968. In addition, the Pohsh institution of Round Table Talks between the regime and the opposition provided a cognitive inodel for all the later transitions.

\section{CONSTRAINTS}

So far I have tried to identify the conditions under which a country enters the constitution-nnaking process. I now turn to my inain topic, which is to understand the inner dynamics of that process. My focus will be on constitution-naking in constituent asseinbhes, although I shall also refer to constitutions that were inore or less miposed by a single pohtical actor.

Consider first the constraints. Although nost constituent assemblies in recent times have been relatively unconstrained, there are soine important exceptions, notably the asseinblies that created the American Constitution, the Frencl Constitution of 1791, and the German Constitution of 1949. This part will focus on these three episodes.

Let ine first distinguish between upstreain and downstream constraints. Upstreain constraints are imposed on the assembly before it starts to deliberate. Downstream constraints are created by the need for ratification of the document the asseinbly produces. As we shall see, this division is soinewhat misleading, but it serves as a useful starting point.

Constituent assemblies are rarely self-created; rather, they have an external creator. In fact, they usually have two creators. On the one hand, there is the institution or individual that makes the decision to convene a constituent assembly. In the United States in 1787, this decision was inade by the Continental Congress. In France in 1789, it was niade by the King. In Germany in 1949 , it was inade by the Western occupying powers. On the other hand, there is the institutional mechanisin that selects delegates to the constituent assembly. In the United States and in Germany, the delegates were selected by the state legislatures. ${ }^{21}$ In Germany, the selection of delegates was subject to a constraint imposed

21. In the U.S., an exception was South Carolina, in which the legislature authorized the governor to choose the delegates. 
by the Allied Powers, namely that their number be proportional to the population of the states. In France in 1789, the delegates were selected by the three estates, with the King having decided that the Third Estate should have as many delegates as the two other estates taken together. ${ }^{22}$

These upstream actors or agencies will often seek to impose constramts on the procedures of the asseinbly or on the substance of the constitution. The Continental Congress instructed the Federal Convention to propose changes to the Articles of Confederation, not to propose an entirely new constitution. The delegates from Delaware came to the Convention with instructions from the state legislature to insist on equality of voting power for all states in the new constitution; in fact, they had asked to be so instructed. In France, many delegates came with instructions froin their constituency to vote for an absolute veto for the King in the new constitution and to insist on voting by estate rather than by head. In Germany, the occupying powers imsisted that the new constitution had to vest most powers in the states because they feared that a strong federal government might give rise to a new authoritarian regime.

Downstream constraints arise froin the process of ratification. If the framers know that the document they produce will have to be ratified by another body, knowledge of the preferences of that body will act as a constraint on what they can propose. In the United States, the fact that the Constitution had to be ratified by the states meant that the framers were not free to ignore the interests of the states. In France, the King claimed a power of veto over the constitution-a veto he was certain to exercise unless he got a veto in the constitution. In Germany, the Allied Powers also reserved for themselves the right to approve the constitution before it was passed on to approval by popular referendum.

We now see why the division between upstream, self-imposed, and downstream constramts is somewhat arbitrary. Typically, the downstream constraints are in fact imposed by the upstream authority. Another even more important difficulty is that the very idea of external constramts is misleading in this context. Constitution-makers do not always respect the mstructions from their up-

22. For the complex origins of this momentous decision, see EGRET, NECKER, MINESTRE DE LOUIS XVI, supra note 9, at 233-48. 
stream creators, including instructions about downstream ratification. And a constraint that can be ignored is no constraint. At the Federal Convention, the framers ignored the instructions froin the Continental Congress on three crucial points when they decided to write an entirely new constitution, to seek ratification by state conventions rather than state legislatures, and to require ratification by nine states rather than by unanimity. In France, the constituent asseinbly decided to ignore the instructions of their constituencies with regard to both the voting procedures and the King's veto. In Germany, finally, the constituent assembly successfully insisted on ratification by the state legislatures rather than by popular referendum. The German frainers also managed to resist soine, although not all, of the decentralizing instructions that the Allies had given them.

The relation between the assembly and its creators can be summarized in two opposing slogans: "Let the kingmaker beware of the king" versus "Let the king beware of the kingmaker." In the three cases I have discussed, the king-the assembly - by and large won out over the kingmaker-the upstream authorities. In Philadelphia and Paris, this outcome was to be expected. Almost by definition, the old regime is part of the problem that a constituent assembly is convened to solve. There would be no need to have an assembly if the regime was not flawed. But if it is flawed, why should the asseinbly respect its instructions?

The German case is more comphicated. The most important factor was that the new political climate created by the Pragne Coup of February 1948 enabled the German framers to ignore many of the instructions of the occupying powers. They successfully argued that ratification by referendum would give a dangerous scope for Communist propaganda. Also, they got a hearing for their claim that an excessively decentralized Germany would be an easy prey for Communist takeover. They were able to play on internal division anong the Allied Powers and exploit the fact that the British wanted to be relieved quickly of the costs of occupation. $^{23}$

23. GolAY, supra note 13 , at $1,8,17,100,110$. 


\section{DESIRES AND BELIEFS}

I now consider the desires and beliefs-the motivations and motivational assumptions-of the framers. On the one liand, the framers themselves may be swayed by a number of more or less respectable motivations. On the other liand, they regularly make certain assumptions about the motivations of future voters, politicians, judges, central bankers, and otler actors whose beliavior is to be regulated by the constitution.

There is no reason to expect these assumptions to mirror the motivations of the framers themselves. The American framers, for instance, certainly saw themselves as moved by loftier motives than those for whom they were legislating. ${ }^{24}$ At the Federal Convention, a dispassionate and disinterested framer sucl as Jaines Madison consistently argued that the Constitution had to be written on the Humean assumption that "every man must be supposed a knave."25 Altlough lie used public clioice arguments, ${ }^{26}$ Madison's own behavior cannot be explamed by public clioice theory.

In discussing these motivations and assumptions, I sliall distinguisl between interest, passion, and reason. ${ }^{27}$ Rouglily speaking, interest divides into personal interest, group imterest, and institu-

24. ARTHUR O. LOVEJOY, REFLECTIONS ON HUMAN NATURE 51-52 (1961).

25. DAVID HUME, ESSAYS: MORAL, POLITICAL AND LITERARY 42 (Eugene F. Miller ed., 1987) (1777). For the influence of Hume on the American framers, see MORTON G. WhITE, PHILOSOPHY, THE FEDERALIST, AND THE CONSTITUTION 13-22 (1987).

26. For some examples, see 2 THE ReCORds OF THE FEDERAL CONVENTION OF 1787, supra note 9 , at $109,114,123$.

27. It is very common to oppose these to each other in a pairwise fashion. David Hume, when addressing the relation between passion and reason, argued that the latter was and ought only to be the slave of the former. DAVID HUME, A TREATISE OF HUMAN NATURE 415 (L.A. Selby-Bigge ed., 2d ed. 1978) (1739-1740). Roughly speaking, he meant that there could be no rational deliberation about ends, only about means. Albert Hirschman has considered the changing attitudes towards passions and interests in the eighteenth century, arguing that the dominance of interest over passion in a commercial society constituted a "pohtical argument[] for capitalism before its triumph." ALBERT O. HIRSCHMAN, THE PASSIONS AND THE INTERESTS at iii (1977). In many discussions of the debates at the Federal Convention, reason and interest are beheved to exhaust the motives of the framers. See JILISON, supra note 9, at 193-94 (citing Madison, Alexander Hamilton, and de Tocqueville to the same effect); see also Jack N. Rakove, The Great Compromise: Ideas, Interests, and the Politics of Constitution Making, 44 WM. \& MARY Q. 424 (1987). Below, I cite a passage from La Bruyère in which all three motivations are considered together. For a discussion of this trio of motives among the American founders, see WHTTE, supra note 25, at 102-12. For a discussion in a different constitutional setting, see REg WHITAKER, Reason, Passion and Interest: Pierre Trudeau's Eternal Liberal Triangle, in A SOVEREIGN IDEA 132 (1992). 
tional interest. Passion divides into sudden or impulsive passions and standing or permanent ones. Reason, finally, is characterized by an impartial concern for the public good or for individual rights. Let ine now consider these motivations in more detail.

\section{A. Interest}

1. Personal Interest. The personal interest of constitutionnnakers in specific constitutional clauses is a relatively inarginal factor, although it does play a certain role in some cases. While few today would defend the Beard thesis that the framers at the Federal Convention were notivated inainly by their own economic interests, ${ }^{28}$ statistical analysis of the vote patterns suggests that these interests have solne explanatory power. ${ }^{29}$ In the inaking of the recent Roinanian and Bulgarian constitutions, several provisions apparently owe their origin to a desire of the former Communists to escape criminal prosecution. ${ }^{30}$

The nost blatant example I know is found in the naking of the Czecl Constitution of 1992. The decision by the Czecl Parliament to create a bicameral parliament in the new constitution was widely seen as an incentive offered to the Czech deputies in the Federal Assembly to pass a constitutional law abolishing the federation in excliange for a place in the new Senate. ${ }^{31}$ It belongs to the story that afterwards the Czech deputies reneged on their promise in order to keep their rivals out of the political binelight. Three years after the adoption of the constitution, elections to the Senate have not taken place or been scheduled. As anotlier example of self-serving constitution-making, one nay cite the unusually strong immunity that the Czech framers granted theniselves, requiring the consent of parhament before criminal prosecution of

28. See Charles A. BeARD, AN Economic Interpretation of the CONSTTUTION OF THE UNITED STATES (1986).

29. Robert A. McGuire, Constitution Making: A Rational Choice Model of the Federal Convention of 1787, 32 AM. J. POL. SCI. 483, 484 (1988).

30. In the Romanian case, this statement is conjectural and based on indirect evidence only. For the Bulgarian case, see Kjell Engelbrekt, Constitution Adopted, Elections Set, RFE Aug. 16, 1991, at 1, 2.

31. See Jiri Pehe, The Waning Popularity of the Czech Parliament, RFE Nov. 12, 1993, at 9; see also Vojtech Cepl \& David Franklin, Senate, Anyone?, E. EUR. ConsT. REV., Spring 1993, at 58, 60 (arguing that even though the decision to create a bicameral parliament was based on self-interest, it had the effect of ensuring an indissoluble, unicameral parliament that has provided governmental stability). 
deputies on any matter whatsoever. In essence, they used the constitution to get rid of traffic penalties. ${ }^{32}$

2. Group Interest. Group interest is a much more important factor in the constitution-making process. At the Federal Convention, the interests of the states were a crucial determinant of the outcome. These interests were reflected both in substantive and procedural provisions of the Constitution. Substantively, the Constitution embodies a compromise between the interests of the slave states and those of the trading states. ${ }^{33}$ Procedurally, the small states successfully insisted on equality of voting power for all states in the Senate. ${ }^{34}$

In the French Assembly of 1789 , the interests of the estates were an important factor in the imitial procedural debates. The nobility and the clergy wanted the assembly to vote by estate, which would enable them to outvote the Third Estate. The Third Estate insisted on voting by head, which would enable them, with the help of a few renegades, to outvote the other two estates. The matter was resolved in favor the Third Estate.

In modern constituent assembles, the interests of political parties are often decisive in shaping electoral laws and various parts of the machinery of government. Typically, large parties prefer majority voting in single-menber districts, whereas sinaller parties insist on proportional elections. The making of several post-Communist constitutions in Eastern Europe illustrates this idea. In the immediate aftermath of 1989 , for instance, the small Communist or ex-Communist parties in Poland and Czechoslovakia insisted on proportional elections. Large parties with a reasonable chance of forming the government may also insist on a constructive vote of no confidence, which strengthens the position of government vis-à-vis parliament. The making of the Spanish Constitution of 1978 illustrates this point. ${ }^{35}$ Parties with a strong presiden-

32. Jan Sokol, Discussions in Prague, in CONSTItutionalism IN EAST Central EUrope: Discussions IN WARSAW, BUdapest, PRAgUe, Bratislava 92, 93 (Irena Grudzinska-Gross ed., 1994).

33. See WILLIAM H. RIKER, THE ART OF POLITICAL MANIPULATION 89-102 (1986); see also Paul Finkelman, Slavery and the Constitutional Convention: Making a Covenant with Death, in BEYOND CONFEDERATION: ORIGINS OF THE CONSTITUTION AND AMERICAN NATIONAL IDENTITY 188 (Richard Beeman et al. eds., 1987).

34. Rakove, supra note 27 , at 424 .

35. BONIME-BLANC, supra note 1 , at 77 . 
tial candidate tend to insist on a strong presidency, whereas other parties try to reduce the power of that office. The making of the Polisl Constitution of 1921 illustrates that connection. ${ }^{36}$

In federally organized states such as Germany, Canada, or the former Czeclioslovakia, the imterests of the states are invariably a key factor. As was the case at the Federal Convention, the smaller states argue for equal representation in the federal government, and the larger states for proportionality. In Czechoslovakia, for instance, Slovakia, with one-third of the population, managed to ensure that half of the judges of the constitutional court would be Slovaks and that the cliairmanship of the central bank would rotate annually between a Czech and a Slovak.

Connections of this kind are commonplaces of political life, and the bread and butter of political scientists. They are coinplicated, however, by another basic fact of political life: Even when groups act to pronote their interest, they tend to argue publicly in terms of impartial values. ${ }^{37}$ When large parties argue for majority voting, they do not refer to the interests of large parties but to the imterest of the country in having a stable government. Conversely, small parties arguing for proportional elections do not refer to the interests of sinall parties but to the values of democracy and broad representation. Parties with a strong presidential candidate regularly argue in terms of the country's need for a strong executive. Other parties refer imstead to the dangers of a strong executive. Both sinall and large states appeal to the impartial value of equality-equal influence of states in the former case, and equal influence of voters in the latter. ${ }^{38}$

A caveat is necessary, lowever. Although it is true that selfserving arguinents tend to dress themselves in public-interest garbs, the converse argument-that all impartial argument is nothing but self-interest in disguise-is imvalid. In some cases, the conclusion is demonstrably false. I give examples later. More generally, the re-

36. See Jon Elster, Bargaining Over the Presidency, E. EUR. CONST. REV., Fall 1993/Winter 1994, at 95,95 .

37. For an argument why a public setting induces public-regarding glosses on private deals, see Jouathan R. Macey, Promoting Public-Regarding Legislation Through Statutory Interpretation: An Interest-Group Model, 86 COLUM. L. REv. 223 (1986).

38. Thus, at the Convention, John Dickinson argued that any scheme that would give some states no representation in the Senate would be "unfair." 1 THE RECORDS OF THE FEDERAL CONVENTION OF 1787, supra note 9, at 159. Madison argued that any deviation from proportional representation was "unjust." Id. at 151. 
ductionist claim is internally incoherent. If nobody was ever moved by the public interest, nobody would have anything to gain by appealing to it. Self-serving appeals to the public interest are parasitic on genuine appeals. ${ }^{39}$

3. Institutional Interest. Institutional interest in the constitution-making process operates when a body that participates in that process writes an important role for itself into the constitution. ${ }^{40} \mathrm{We}$ can observe this factor at work in inany cases, as in the making of the Polisl Constitution of 1921 or the French Constitution of 1946. In botl cases, the parliament that wrote the constitution did its best to reduce the role of the executive and to proinote the role of parliament. I conjecture that institutional interest has also been the inost important factor in the inaking of the post-1980 constitutions in Eastern Europe. Let ine briefly sketch four implications of that lypothesis and see how well they are verified.

A first implication is that constituent assemblies that also serve as ordinary legislatures will give preponderant importance to the legislative brancl at the expense of the executive-president and cabinet-and the judiciary. In Eastern Europe, this implication is relatively well confirmed. All the constituent assemblies were also ordinary legislatures. Except in Poland, the presidents are not strong. That exception does not, lowever, count as evidence against the liypothesis, as the presidency in that coimtry was an artifact of the Round Table Talks rather than the creation of a deinocratic asseinbly. Except for Hungary, whicl adopted the constructive vote of no confidence, no country has adopted provisions that would strengthen the position of the executive vis-à-vis parliainent. ${ }^{41}$ It counts agamst the lypothesis, however, that the consti-

39. Cf. ELSTER, supra note 3, at 125 (discussing the analogous relationship between social norms and self-interest).

40. If one believes, as I do, in methodological individualism, talk about group interest and institutional interest can never be more than shorthand for individuals' motivations. If members of a parliamentary caucus, for instance, do not follow the party line, they may fail to get renominated or reelected, or suffer financial sanctions. In other cases, legislators seein to identify with the institution to which they belong. Independent of reelection, they tend to feel pride in their institution because of a need for cognitive consonance ("This must be an important institution since I am a member of it") or through socialization.

41. In the Roinanian Constitution, lowever, there is a provision (Art. 113) that allows the executive to engage its responsibility on a law, so that it is automatically passed 
tutional courts are quite strong, except for Poland and Romania, where their decisions can be overruled by parliament with a twothirds majority (Romania) or even a simple majority (Poland). ${ }^{42}$

A second implication is that unicameral and bicameral constituent assemblies will tend to create, respectively, unicameral and bicaneral constitutions-a prediction that is largely born out. Bicanieral assemblies in Poland and Romania created bicameral constitutions; unicaneral assemblies in Hungary, Slovakia, and Bulgaria created unicaneral constitutions. The only exception to the pattern is the Czech Republic, where, as indicated earlier, a unicameral assembly created a bicameral constitution as an incentive for the Czech deputies to the upper house of the Federal Assembly to vote for the dissolution of the federation.

A third implication is that to the extent that the president is mvolved in the constitution-making process, he will tend to promote a strong presidency. Here, the distinction between personal and imstitutional interests may be a tenuous one. Yet it appears to me that Walesa and Havel, in their efforts to strengthen the presidency, have not simply been out to enhance their own power. Rather, I believe that froin their vantage point the advantages of a strong presidency, which can prevent chaos and ensure efficiency in the difficult transition period, have seemed obvious and overwhelming.

A final imphication is that constitution-making parliaments will give themselves large powers to amend the constitution. In particular, their institutional interest would not recommend that changes in the constitution be submitted to referendum or be adopted by two successive parhiaments. With the exception of Romania, where approval by referendum is mandatory, this implication is confirmed. The importance of the Rounanian exception is attenuated by the fact that the deputies can change the constitution by the

unless parliament votes a motion of no confidence. This provision is very similar to Art. 49(3) of the French Constitution of 1958. Although it was supposed to be used only exceptionally, see Connité Consultif Constitutionnel (Aug. 12, 1958), in 2 DocumENTS POUR SERVIR A L'HISTOIRE DE L'ÉLABORATION DE LA CONSTITUTION DU 4 OCTOBRE 1958, supra note 16 , at $367,505-06$, Art. $49(3)$ has been an extremely efficient tool in the liands of successive governments. The Romanian provision lias not had a similar importance.

42. Although the statutory law regulating the Polish court says that a two-thirds majority is ueeded, that statute itself can be changed by simple majority. 
"backdoor" procedure of overruling decisions by the constitutional court.

By and large, therefore, the hypothesis that constitution-makers are motivated by imstitutional interest fares quite well in Eastern Europe. Whereas group interest has strong explanatory power with regard to electoral laws, institutional interest is a stronger determinant of the machinery of government. Institutional interest fails, however, to explain the creation of strong constitutional courts, an institution that was nowhere represented in the constitution-making process and that nevertheless did quite well out of it. Along another dimension, the hypotheses do less well in Hungary than in the other countries. By adopting the constructive vote of no confidence and creating a strong constitutional court, the Hungarian constitution-makers abdicated some of their most important powers. It is possible, though, that they did not intend or foresee that the court would become as strong as it has turned out to be. ${ }^{43}$

\section{B. Passion}

I now turn to the role of passions-sudden or permanent-in constitution-ınaking. Let me first digress for a moinent froin the motives of the framers to consider the motives of the framed, if I may use that expression to designate the actors whose behavior is to be regulated by the constitution. From a traditional view, a key role of the constitution is to prevent the framed from acting on sudden, unconsidered impulses: "Constitutions are chains with which men bind themselves in their sane moments that they may not die by a suicidal hand in the day of their frenzy."44 This restraining function is achieved partly by built-in delays in the ma-

43. The Hungarian constitutional court has been called the strongest in the world. See Ethan Klingsberg, Judicial Review and Hungary's Transition from Communism to Democracy: The Constitutional Court, the Continuity of Law, and the Redefinition of Property Rights, 1992 B.Y.U. L. REV. 41.

44. JOHN E. FINN, CONSTITUTIONS IN CRISIS 5 (1991) (quoting John Potter Stockton in debates over the Ku Klux Klan Act of 1871). On the general theme of self-binding, see JON Elster, ULYSSES AND THE SiRENS ch. II (1979) and Stephen Holmes, Precommitment and the Paradox of Democracy, in CONSTITUTIONALISM AND DEMOCRACY 195 (Jon Elster \& Rune Slagstad eds., 1988). On the theine of constitutional self-binding, see Jon Elster, Intertemporal Choice and Political Thought, in CHOICE OVER TrMe 35, 35-45 (George Loewenstein \& Jon Elster eds., 1992). For a discussion of the putative paradoxes involved in self-binding, see PETER SUBER, THE PARAdOX OF SELF-AMENDMENT 1-16 (1990). 
chinery of government, such as bicameralism and suspensive veto, and partly by time-consuming amendment procedures.

Similarly, it has been argued that the constitution should protect ethnic or religious minorities from oppression by majorities that are subject to permanent passions and prejudice. As Cass Sunstein writes, "Constitutional provisions should be designed to work against precisely those aspects of a country's culture and tradition that are likely to produce most harm through that country's ordinary political processes." ${ }^{34}$ A bill of rights is the most prominent instrument for ensuring that protection. Another mechanism is to reserve some seats in parliament for minority groups.

It would indeed be a good thing if constitutions could serve these two functions. They will do so, however, ouly if the conditions of the framers are sufficiently different from those of the framed. But consider the analogy that constitutions are chams imposed by Peter when sober on Peter when drunk. ${ }^{46}$ If constitutions are typically written in times of crisis, it is not obvious that the framers will be particularly sober. The French constitutionmakers of 1791 , for instance, were not fanous for their sobriety, and the document they produced, which esclews bicameralism as well as judicial review, contams few devices for restraining nnajorities that are swept by passion.

Similarly, the framers will typically be subject to the same standing passions and prejudices as the framed. As observed by Adam Przeworski and Fernando Limongi, "[A]dvocates of commitment ... do not consider the political process by which such commitments are establislied." ${ }^{47}$ In Bulgaria, for instance, one might wish for the constitution to protect the rights of the Mushin, Turkish-speaking minority against oppression by ethnic Bulgarians. The fact is, however, that the latter exploited their control of the constitution-making process in 1990-1991 to adopt some of the most illiberal provisions in the new East European constitutions. ${ }^{48}$

45. Cass R. Sunstein, Constitutionalism, Prosperity, Democracy: Transition in Eastern Europe, in 2 CONST. POL. ECON. 371, 385 (1991).

46. Holmes, supra note 44 , at 196.

47. Adam Przeworski \& Fernando Limongi, Political Regimes and Economic Growth, J. ECON. PERSP., Summer 1993, at 51, 66.

48. Standing passions can be overcome, though, if the constitution is written under foreign supervision or by a small and enlightened minority within the country. The illiberal provisions in the first draft of the recent Romanian Constitution were eliminated 
There is one particular passion that has, somewhat surprisingly, played a considerable role in constitution-1naking. This is vanity or self-love, amour-propre, which many norahsts from La Rochefoucauld onwards have considered the most powerful human emotion. Not surprisingly, we find it both in the framers and in the assumptions they make about the framed.

Consider first vanity, or rather fear of the effects of vanity, in the framers. At the Federal Convention, the delegates decided at the outset to adopt a rule of secrecy because they understood themselves well enough to know that if they had once adopted a position in public, vanity might keep then from changing their mind later. As Madison said later, "Had the niembers committed themselves publicly at first, they would have afterwards supposed consistency required thein to naintain their ground, whereas by secret discussion no man felt himself obliged to retam his opinions any longer than he was satisfied of their propriety and truth, and was open to the force of argument." 49 I shall argue, however, that secrecy may also tend to inove the proceednigs away from discussion and towards threat-based bargaming.

Consider next vanity in the framed. At the first French Assenibly, many speakers asserted that one should never place an agent in a situation in which his vanity might lead him to act against the public interest. The prosecutor also should not serve as judge because if the functions are conibimed, the amour-propre of the magistrate might bias him towards the guilt of the accused. ${ }^{50}$ A merely suspensive veto for the king would not have the intended effect of niaking the assembly reconsider its decision because its amour-propre would prevent it fronı backing down. ${ }^{51}$

\section{Reason}

Another French inoralist, La Bruyère, wrote that "[n]othing is easier for passion than to overconie reason: its great triumph is to win out over interest." ${ }^{52}$ Sometimes, however, reason can wim out

after strong pressure from the Council of Europe. And it is at least arguable that the standing passion for levelling equality among the Americans was overcome by the elitist Constitution of 1787.

49. 3 THE Records of THE FEDERAL CONVEntion of 1787, supra note 9, at 479.

50. See 8 ARCHIVES PARLEMENTAIRES, supra note 9, at 443.

51. See 9 ARChIVES PARLEMENTAIRES, supra note 9, at 111.

52. La Bruyère, Caractères, in 1 Collection des Meilleurs Auteurs 3, 75 (Librarie de Ia Bibliothèque Nationale, 1899) (translation by author). 
over passion as well as interest. In fact, we just saw an example. When the framers at the Federal Convention decided to proceed behind closed doors, it was because their reason told thein that otherwise they might yield to passion. They did not conquer passion, perhaps, but preempted it.

Similarly, when the French delegates of 1789 adopted Robespierre's proposal for a law that would render them ineligible to the first ordinary legislature, it was because they wanted to shield themselves from institutional interest. More generally, the exceptions that I noted earher about the tendency for East European constituent parliaments to favor parliament in the constitution can also be seen as expressions of impartial, disinterested motivations.

Let me give another example of such counter-interested behavior. Immediately after the fall of Communisin in Czechoslovakia, Vaclav Havel and his advisors from Civil Forum undertook to write the electoral law for the elections to the constituent assembly. Havel strongly favored the majority system because it would allow the voters to select individuals rather than parties. The majority systen would also have allowed Civil Forum to sweep the elections, as Solidarity had done in Poland in June 1989. For Havel and his group, however, the latter fact counted agamst the majority system rather than for it. They dehberately pulled their punches and adopted a proportional mode of election because they wanted a broad representation of all political tendencies, including the Communists, in the first parliament. As one of Havel's close collaborators told me, "This decision will be seen either as the glory or the weakness of the November revolution: we were winners that accepted a degree of self-limitation."

Froin the Federal Convention, I can cite another discussion that pits interest agamst reason. Elbridge Gerry had proposed to "limit the number of new States to be admitted into the Umon, in such a manner, that they should never be able to outnumber the Atlantic States." ${ }^{, 53}$ In his reply, Roger Sherman relied on personal interest to overcome group interest. "We are providing," he said, "for our posterity, for our children and our grand Children, who would be as likely to be citizens of new Western States as of the old States. $\$ 54$

53. 2 THE RECORDS OF THE FEDERAL CONVENTION OF 1787, supra note 9, at 3.

54. Id. A similar argument was offered by George Mason in a different context: 
Neither argument should be confused with genuine appeals to impartiality, as in Mason's argument for granting new states equal status: "Strong objections have been drawn," he said, "from the danger to the Atlantic interests from new Western states." $\mathrm{He}$ went on to say, however, that the delegates ought not "to sacrifice what we know to be right in itself, lest it should prove favorable to States which are not yet in existence. If the Western States are to be admitted into the Union as they arise, they must," he insisted, "be treated as equals, and subjected to no degrading discrimination." 55 This argument does not rest on the long-term interests of family lines, but on a conception of intrimsic fairness.

\title{
IV. Aggregation, TRANSFORMation, AND MisReP- RESENTATION OF PREFERENCES
}

Given their motivations and cognitive assumptions, constitutional framers form preferences regarding the various institutional arrangements that are proposed. In this part, I discuss how these preferences come together, as it were, to produce a collective decision.

It is not simply a question of aggregating given preferences by a given procedure. For one thing, the procedure has itself to be chosen by the delegates. In France in 1789, as I said, the delegates had to choose between voting by estate and voting by head. In Philadelphia, they had to choose between equal voting power for all states at the Convention and giving more votes to the heavily populated states. ${ }^{56}$ In the first case, they adopted the primciple

\begin{abstract}
We ought to attend to the rights of every class of the people. He had often wondered at the indifference of the superior classes of society to this dictate of humanity \& policy, considering that however affluent their circumstances, or elevated their situations, might be, the course of a few years, not only might but certainly would, distribute their posterity throughout the lowest classes of Society. Every selfish motive therefore, every family attachment, ought to recommend such a system of policy as would provide no less carefully for the rights and liappiness of the lowest than of the highest orders of Citizens.
\end{abstract}

1 THE RECORDS OF THE FEDERAL CONVENTION OF 1787, supra note 9, at 49. 579.

55. 1 THE RECORDS OF THE FEDERAL CONVENTION OF 1787, supra note 9, at 578,

56. Actually, the latter proposal was only fleetingly entertained. Although the Pennsylvanians wanted to refuse the srialler states an equal vote, their proposal was never put on the table. See 1 THE RECORDS OF THE FEDERAL CONVENTION OF 1787, supra note 9, at 10 n.4. When a committee was formed to forge a compromise on the upper house, Janues Wilson "objected to the Committee because it would decide according to that very rule of voting which was opposed on one side," but to no avail. Id. at 515 . 
"one man, one vote"; in the second, "one group, one vote."

In most other assemblies, it is usually taken for granted that decisions will be reached by a simple majority of the delegates. Yet some assemblies have decided from the beginning to aim at something close to consensus. This was the case, for imstance, in the making of the 1949 German Constitution and the 1978 Spanish Constitution. To avoid confrontation and achieve consensus, the Spanish framers early on made a number of important procedural decisions. They successfully imposed secrecy on the committee proceedings and decided that the parties should not be allowed to present whole constitutional drafts, only drafts of imdividual provisions. ${ }^{57}$

For another thing, we caimot assume that delegates simply express given preferences or follow instructions from their constituencies. As I mentioned above, the delegates to the Federal Convention imposed secrecy on the debates to make it easier for thein to change their minds through discussion. In the first French Assembly, imperative inandates were rejected for the same reason. In the best-known statement of this view, Abbe Sieyès argued that the "voeu national," the desire of the nation, could not be determined by consulting the cahiers of complaints and wishes that the delegates had brought with them to Versailles. Bound mandates, similarly, could not be viewed as expressions of the national will. In a democracy (a term that was used pejoratively at the time), he said, people form their opimions at home and then bring them to the voting booth. If no majority emerges, they go back home to reconsider their views, once agam isolated from each other. This procedure for forming a common will, he claimed, is absurd because it lacks the element of dehberation and discussion: "It is not a question of a democratic election, but of proposing, listening, concerting, changing one's opinion, im order to form in common a comınon will." $" 58$

Generally speaking, preferences can undergo two different kinds of changes before they enter as inputs to the aggregation process. First, as I have said, there is transformation of preferences through discussion. People may change their derived preferences

57. Jose Pedro Pérez-Llorca, Commentary, in CONSTITUTION MAKERS ON CONSTITUTION MAKING, supra note 1, at 266, 271-72 (commenting on Rubio Llorente, supra note 14).

58. 8 ArChives Parlementaires, supra note 9, at 595 (translation by author). 
when they get new information about ends-means relationships. Less frequently, perhaps, they may change their fundamental preferences as a result of normative argument. Second, there is the possibility of misrepresentation of preferences. For a number of reasons, delegates may, in their speeches and votes, express preferences other than those they actually have.

The scope for both kinds of change depends on whether the framers debate publicly or behind closed doors. I have already indicated that secrecy of the debates is likely to have two consequences. On the one hand, it will tend to shift the center of gravity from impartial discussion to imterest-based bargaining. In private, there is less need to present one's proposal as aimed at promoting the public good. On the other hand, secrecy tends to improve the quality of whatever discussion does take place because it allows framers to change their mind when persuaded of the truth of an opponent's view. Conversely, while public debate drives out any appearance of bargaining, it also encourages stubbornness, overbidding, and grandstanding in ways that are imcompatible with genuine discussion. Rather than fostering transformation of preferences, the public setting encourages their misrepresentation.

The Federal Convention and the first French Assembly are polar cases in this respect. In Madison's notes from the Convention, we come across some exceptionally fine instances of rational discussion and some exceptionally hard bargams. In the records of the French Assembly we find neither. The speakers argue without exception in terms of the public interest. We know from other evidence, however, that because of publicity-generated fear of sanctions, inany of the constituants spoke and voted against their convictions. ${ }^{59}$ The radical delegates insisted on voting by roll call, a procedure that enabled nembers or spectators to identify those who opposed radical measures and to circulate lists with their names in Paris. The defeat of bicameralism and of an absolute veto for the King, in particular, owed much to the fear generated by this publicity. ${ }^{60}$

A very different source of imisrepresentation is directly linked to the process of aggregation. When the framers of a constitution vote on the various issues that are before them, vote-trading oc-

59. EGRET, LA REVOLUTION DES NOTABLES, supra note 9, at $\mathbf{1 2 0 .}$

60. Id. at 154 . 
curs on a regular basis. A delegate may vote against his true preferences on an issue he cares hittle about, but that matters very much to another delegate, in exchange for a similar concession by the other.

In the first French Assembly, a famous piece of logrolling took place in the last days of August 1789 when the Assembly was about to debate the basic institutions of the state. ${ }^{61}$ In three meetings between Mounier on the one hand and the "triumvirate" of Barnave, Duport, and Alexandre Lameth on the other, the three came up with the following proposal: They would offer Mounier both an absolute veto for the King and bicaneralism if he in return would accept that the King give up his right to dissolve the asseinbly, that the upper chamber would have a suspensive veto only, and that there would be periodical conventions for the revision of the constitution. ${ }^{62}$ Mounier refused outright. ${ }^{63}$ According to his own account, he did not think it right to make concessions on a matter of principle. ${ }^{64} \mathrm{He}$ may also have been in doubt about the ability of the three to deliver on their promise. According to later historians, he refused because he was so confident that the Assenibly was on his side that no concessions were needed. ${ }^{65}$ As I just mentioned, he was wrong.

Note that logrolling of this sort is difficult if the constituent assembly is deeply polarized around one issue. The break-up of Czechoslovakia may be understood in this perspective. Here the constitution-nıaking process was polarized around the problem of the federation. No other issues were important enougll for logrolling to be possible. Moreover, it is arguable that separation was the only coinpromise solution, being the second-best option of both sides.

The making of the Spanish Constitution of 1978 involved logrolling on a large scale, witl the main issues benig the role of the Church, the autonomy of the provinces, and socioeconomic policy. Because of the presence of several issues that could be

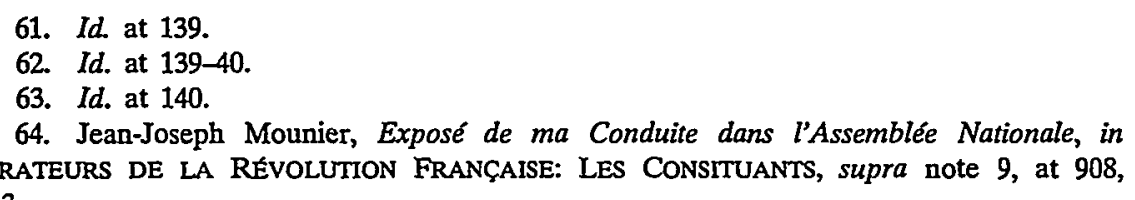
933.

65. A. Mathiez, Etude Critique sur les Journées des 5 \& 6 Octobre 1789, 67 REVUE HISTORIQUE 241, 267 (1898). 
traded off against each other, it was possible to reach a high degree of consensus. ${ }^{66}$ Earker constitution-making efforts in Spain had been more polarized. The 1931 Spanish Constitution, for instance, was adopted by a small majority that imposed dogmatic, leftist, and secular principles on their opponents.

Aggregation by voting is inherently vulnerable to cycling. William Riker demonstrated the existence of a cycle at the Federal Convention in the matter of the Presidency, with the cycling options being election by Congress with the concurrence of both Houses, election of the President by electors chosen by the states in proportion to their population, and election by a joint session of the House and the Senate. According to Riker, the revelation of this cycle prevented the second alternative from being adopted, and prepared the way for the final compromise in which the small states got to choose a more-than-proportional number of electors. $^{67}$

Finally, I shall consider the role of threat-based bargaining as a mechanism of aggregation. Vote trading may of course also be considered in this perspective, with the threat being that of withholding one's vote on an issue of vital importance to the opponent. But what $I$ have in mind here is bargaining based on resources that are not created by the political system, but that exist independently of the assembly itself. These include foreign powers, police, military forces, terrorism, command over crowds, and electoral prospects. Because constitutions tend to be made in a crisis, these extra-political resources often play a prominent role. Time and the ability to hold out is also an important resource that confers credibility on threats in sucli cases.

Many constitution-making processes have been suspended in fields of extra-political forces. I shall illustrate with examples from the two eighteenth-century assembhes, and then very briefly inention some more recent cases.

At the Federal Convention, we find several references to extra-political forces, notably in the debates over the representation of the sinall states in the Senate. On June 30, Gunning Bed-

66. COLOMER, supra note 14 , at 78-104.

67. William H. Riker, The Heresthetics of Constitution-Making: The Presidency in 1787, with Comments on Determinism and Rational Choice, 78 AM. POL. SCI. REV. 1, 12-13 (1984); see also RIKER, supra note 33, at 34-51. COLOMER, supra note 14, at 91-101, contains similar examples from the Spanish transition. 
ford, Jr. asserted that "[t]he Large States dare not dissolve the confederation. If they do the small ones will find some foreign ally of more honor and good faith, who will take them by the hand and do them justice. He did not mean by this to imtimidate or alarm. It was a natural consequence which ought to be avoided by [e]nlarging the federal powers not annihilatimg the federal system."

\section{On Jnly 5, Gouverneur Morris counterattacked:}

Let us suppose that the larger States shall agree; and that the smaller refuse: and let us trace the consequences. The opponents of the system in the smaller States will no doubt make a party aud a noise for a time, but the ties of interest, of kindred \& of coinmon habits which connect thein with the other States will be too strong to be easily broken. In N. Jersey particularly he was sure a great many would follow the sentiments of Pena. \& N. York. This Country must be united. If persuasion does not unite it, the sword will. He begged that this consideration might have its due weight. The scenes of horror attending civil commotion can not be described, and the conclusion of thein will be worse than the term of their continuance. The stronger party will then make traytors of the weaker; and the Gallows \& Halter will finish the work of the sword. How far foreign powers would be ready to take part in the confusions he would not say. Threats that they will be invited have it seems been thrown out. ${ }^{69}$

Later, both sides retreated by rephrasing their threats as warnings. ${ }^{70}$ This is a widely observed stratagem. In the Polish Round Table Talks in 1989, for instance, the government negotiators were

68. 1 The ReCORDS OF the Federal CONVENTION OF 1787, supra note 9, at 492 .

69. Id. at 530 .

70. The terminology on this point is not settled. Kent Greenawalt refers to "warning threats," as if an utterance could be both a threat and a warning. KENT GREENAWALT, SPEECH, CRIME, AND THE USES OF LANGUAGE 251 (1989). Other writers have used the distinction between warning and threat to differentiate between cases in which the actor has an incentive to carry out the announced action and those in which he does not. See Thomas C. SCHELING, THE STRATEgy of CONFLICT 123 n.5 (1960); see also Robert Nozick, Coercion, in PHILOSOPHY, SCIENCE AND METHOD 440, 453-58 (Sidney Morgenbesser et al. eds., 1969) (distinguishing warnings from threats on the ground that the former simply describes what will follow as a consequence of a particular action while the latter contains an element of coercion). Thus, to tell a burglar that I will call the police unless he goes away is to warn him; to tell a girl that I will commit suicide if she does not consent to marry me is to make a threat. In the present Essay, the distinction is used to contrast the outcomes that are within the control of the agent and those that are not. See also infra note 72. 
careful not to brandish the threat of Soviet intervention. Instead, they warned the Solidarity negotatiors that if heralization went too far, the Soviets were likely to intervene, which was against the wishes of both sides.

In France in 1789, the field of force was defined by the royal troops in the vicinity of Versailles and the crowds in Paris. When in the first days of July the King reinforced the presence of troops near Versailles, the imphed threat to the assembly escaped no one. Mirabeau's rephes to the King's challenge were, however, subject to the threat-warning ambiguity. In his first speech on the subject, he spoke in quite general terms: "How could the people not become upset when their only remaining hope [i.e., the assembly] is in danger?"71 In his second speech, he became inore specific: The troops "may forget that they are soldiers by contract, and remember that by nature they are men." 72 Furthermore, the assembly cannot even trust itself to act responsibly: "Passionate movements are contagious: we are only men, our fear of appearing to be weak inay carry us too far in the opposite direction."73

In his brief intervention in the same debate, Sieyès inentioned that in all deliberative assembhes, notably in the Estates of Brittany, the Assembly refused to deliberate if troops were located closer than twenty-five miles from where it was sitting. ${ }^{74}$ When the Assembly asked for the removal of the troops, however, the King in his response pretended that they had been brought to control Paris rather than to terrorize the Assembly. ${ }^{75}$ If the Assembly took objection to the presence of troops in the vicinity of Paris, he would be perfectly happy to move the Assembly to Noyon or Soisson, and to move himself to Compiègne so as to facilitate coinununication between them. However, the Asseinbly could not accept a proposal that would deprive them of the threat potential of Paris. It was decided to send a delegation to the King, asking him to recall the troops "whose presence adds to the des-

71. 8 ARCHIVES PARLEMENTAIRES, supra note 9, at 209 (translation by author).

72. Id. at 213. This is an instance of a self-fulfilling warning, which is, in a sense, intermediate between ordinary warnings and threats. By publicly telling the King that his troops were unrehable, Mirabeau may in fact have ensured the truth of that statement. For another instance of this idea, see CONOR C. O'BRIEN, THE GREAT MELODY: A THEMATIC BIOGRAPHY AND COMMENTED ANTHOLOGY OF EDMUND BURKE 125 (1992).

73. 8 ARCHIVES PARLEMENTAIRES, supra note 9, at 213 (translation by author).

74. Id. at 208.

75. Id. at 219. 
peration of the people." ${ }^{\text {76 }}$ If the King agreed, the Assembly would send a delegation to Paris "to tell the good news and contribute to a return of order." 77 There was no need to say what they would do if he failed to accommodate them. The next day the Bastille fell, and the King agreed to send the troops away.

The same forces-the troops and the crowds-were at work in Paris in 1848. In Paris in 1958, the prospect of military rebellion was a major factor enabling de Gaulle to impose his constitution. In Frankfurt in 1848, the constitution-making process was punctuated by the murder of a promment right-wing member of the assembly. In Weimar in 1919, revolutionary workers and the victorious enemy were both instrumental im shaping the constitution. In Bonn in 1949, the German framers cleverly used the Communist scare in their bargaining with the Western occupying powers. In Spain in 1978, the constitution-making took place $\mathrm{m}$ an atmosphere heavily influenced by the Francoist army and Basque terrorists. In Eastern Europe, the quasi-constitutional Round Table Talks were suspended between threats or warnings of Soviet intervention on the one hand, and the potential for mass demonstrations by the workers on the other.

We can draw on game theory and bargaining theory to model these influences explicitly ${ }^{78}$ as long as we remain conscious of the limitations of that approach. In situations like those I just invoked, people do not always act rationally. Fear, anger, and enthusiasm often get the better of them. Nor can they easily estimate the likelihood of the various contingencies. In these situations, constitution-inaking has more of the opaqueness of battle than the calculability of parhamentary proceedings. Formal theory helps us to make more precise sense of soine of the factors we can identify, but it hardly allows for a complete explanation.

76. Id. at 229 .

77. Id.

78. Examples of game-theory and bargaining theory applied to processes of transition in general and to constitution-making more specifically imclude COLOMER, supra note 14; ADAM PRZEWORSKI, DEMOCRACY AND THE MARKET (1991); RIKER, supra note 33; Jon Elster, Argumenter et Négocier dans Deux Assemblées Constituantes, 44 REVUE FRANÇAISE DE SCIENCE POLITIQUE 187 (1994); Douglas D. Heckathorn \& Steven M. Maser, Bargaining and Constitutional Contracts, 31 AM. J. POL. SCI. 142 (1987); Riker, supra note 67; Jakub Zielinski, The Polish Transition to Democracy: A Game-theoretic Approach, 36 ARCHIVES EUROPÉENES DE SOCIOLOGIE 135 (1995). 


\section{CONCLUSION}

Let me conclude by underlining two basic paradoxes of constitution-making and then drawing some normative implications of the analysis. The first paradox arises from the fact that the task of constitution-making generally emerges im conditions that are likely to work against good constitution-making. Being written for the indefinite future, constitutions ought to be adopted in maximally calm and undisturbed conditions. Also, the intrinsic importance of constitution-making requires that procedures be based on rational, impartial argument. In ordmary legislatures, logrolling and horsetrading may ensure that all groups realize some of their most strongly held goals. Constitution-makers, lowever, legislate mainly for future generations, which have no representatives in the constituent assembly. It is part of their task to look beyond their own horizon and their own interests. At the same time, the call for a new constitution usually arises in turbulent circumstances, whicl tend to foster passion rather than reason. Also, the external circumstances of constitution-making invite procedures based on threat-based bargaining. Marx said that "mankind always sets itself only such tasks as it can solve." In constitution-making, by contrast, it seems that the task is set only under conditions that work against a good solution.

The second paradox stems from the fact that the public will to make major constitutional cliange is unlikely to be present unless a crisis is impending. Suppose, for example, that constitutional cliange is put on the agenda even though there are no dranatic external circumstances. In that case, no solution may be found at all. As Peter Russell writes, "A country must have a sense that its back is to the wall for its leaders and its people to have the will to accommodate their differences." ${ }^{\prime 80}$ In Canada after 1982 and in Poland after 1992, we can observe how constitution-making failed to get off the ground because there was no urgent need to resliape the basic institutions. It is an axiom of bargaining theory that "[i]f it did not matter when people agreed, it would not matter whetler or not they agreed at all." ${ }^{181}$ If people find themselves with all the

79. KARL MARX, Preface to A Critique of Political Economy, in KARL MARX: A READER 187, 187 (Jon Elster ed., 1986).

80. RUSSELL, supra note 16 , at 106 .

81. John G. Cross, $A$ Theory of the Bargaining Process, S5 AM. ECON. REV. 67, 72 (1965). 
time they need to find a good solution, no solution at all may emerge.

I conclude with some comments on the normative implications that may be drawn from the arguments made above. The most important is perhaps that to reduce the scope for institutional interest, constitutions ought to be written by specially convened assemblies and not by bodies that also serve as ordinary legislatures. Nor should the legislatures be given a central place in the process of ratification. In both these respects, the Federal Convention can serve as a model. Another implication is that the process ought to contain both elements of secrecy (committee discussion) and of publicity (plenary assembly discussions). With total secrecy, partisan interests and logrolling come to the forefront, whereas full publicity encourages grandstanding and rhetorical overbidding. At the Federal Convention, there was too little publicity; in the French Assembly of 1789 , too much. The making of the 1978 Spanish Constitution may have come closer to the optimal balance. 82

More tentatively, I also suggest the following recommendations: (1) Elections to the constituent assembly ought to follow the proportional systein rather than the majority system. Whatever the advantages of the majority system in creating ordinary legislatures, a constituent assembly ought to be broadly representative. ${ }^{83}$ (2) The constituent assembly ought to be unicameral, not bicameral. Whatever the arguments for having bicameralism in ordinary legislatures, they do not apply to the constituent assembly. (3) To reduce the scope for threats and attempts to influence the deliberations by mass demonstrations, the assembly should not convene in the capital of the country or in a major city; nor should armed forces be allowed to sojourn in the vicinity of the assembly. (4) The role of experts should be kept to a minimum because solutions tend to be more stable if dictated by political rather than technical considerations. Lawyers will tend to resist the technically flawed and deliberately ambiguous formulations that may be necessary to achieve consensus. (5) The assembly should work with a time limit, so that no group can use delaying tactics to get its way. (6) If delays are affordable, the constitution should not come into

82. BONIME-BLANC, supra note 1 , at 36 . 30.

83. Wiktor Osiatynski, Poland's Constitutional Ordeal, 1994 E. EUR. CONST. REv. 29, 
effect until some time after it has been adopted to reduce the impact of short-term and partisan motives. As new constitutions usually are called for in times of crises, however, delays will rarely be affordable. Again, we encounter the paradox that the need for constitution-making tends to emerge under conditions that systematically work against the impartial and far-sighted reasoning for which the task calls. 